\title{
Bilateral complex regional pain syndrome following spinal cord injury and bilateral calcaneus fracture
}

\author{
Spinal kord yaralanması ve bilateral kalkaneus kırığı sonrası bilateral kompleks bölgesel ağrı \\ sendromu
}

Ahmet Boyacl ${ }^{1}$, Ahmet Tutoğlu ${ }^{1}$, F. Nurefşan Boyacl ${ }^{2}$, Esra Çelen ${ }^{1}$

\begin{abstract}
Complex regional pain syndrome (CRPS) is a disease affecting one or more extremities, characterized by spontaneous pain, allodynia, hyperpathia and hyperalgesia. CRPS is separated into Type 1 and Type 2. CRPS which develops after a nociceptive event is labeled as Type 1 and when it develops following peripheral nerve damage, Type 2. Although the pathogenesis is not fully understood, peripheral and central sensitivity are held responsible. Bilateral lower extremity involvement is extremely rare. However, it should be borne in mind that it can develop in traumatic injuries which occur in more than one area and diagnosis and commencement of a rehabilitation program should be made in the early period. The case is presented here of bilateral Type 1 CRPS developing after incomplete spinal cord injury and bilateral calcaneus fracture. $J$ Clin Exp Invest 2013; 4 (3): 360-363
\end{abstract}

Key words: complex regional pain syndrome, calcaneus fracture, spinal cord injury

\section{INTRODUCTION}

Complex regional pain syndrome (CRPS) is a disease, characterized by pain, which develops following regional damage. In $10 \%$ of cases, CRPS may develop as a result of minor trauma or without any trauma [1]. CRPS is a disease localized to the extremity, characterized by sensory, autonomic, motor, skin and bone changes but the main symptom is pain. It is also known as reflex sympathetic dystrophy (RSD), algodystrophy, algoneurodystrophy, Sudeck's atrophy and causalgia [2]. Reasons such as fractures, soft tissue injuries, head trauma, hemiplegia, myocardial infarction, carpal tunnel decompression, back surgery and arthroscopy are in the etiology [3]. This is a syndrome characterized by pain disproportionate to the injury, allodynia, hy-

\section{ÖZET}

Kompleks bölgesel ağrı sendromu (KBAS), vücudun bir veya daha fazla ekstremitesini etkileyen, spontan ağrı, allodini, hiperpati ve hiperaljeziyle karakterize bir hastalıktır. KBAS tip 1 ve tip 2 olmak üzere ikiye ayrılır. Nosiseptif olayı takiben gelişen KBAS tip 1 ve periferik sinir yaralanmasını takiben gelişen ise KBAS tip 2 olarak adlandırıır. Patogenezi tam anlaşılamamış olmakla birlikte periferik ve santral duyarlılık sorumlu tutulmaktadır. Bilateral alt ekstremite tutulumu oldukça nadir bir durumdur. Fakat birden fazla bölgede meydana gelen travmatik yaralanmalarda gelişebileceği akılda tutulmalı ve erken dönemde tanı konup rehabilitasyon programına başlanmalıdır. $\mathrm{Bu}$ olgu sunumunda inkomplet spinal kord yaralanması ve bilateral kalkaneus kırığı sonrası bilateral KBAS tip 1 gelişen bir olgu sunuldu.

Anahtar kelimeler: Kompleks bölgesel ağrı sendromu, kalkaneus kırığı, spinal kord yaralanması

peralgesia, changes in temperature and color of the affected extremity and abnormal sudomotor activity [4]. There is no diagnostic test for CRPS. Diagnosis is based on specific symptoms and findings. The success of the treatment and prevention of complications depends on early diagnosis [3].

The case is presented here of a patient with spinal cord injury and bilateral calcaneus fracture resulting from a fall from height in whom Type 1 CRPS developed in both feet after removal of the plaster cast.

\section{CASE REPORT}

An 18-year old female presented with complaints of pain in both feet, swelling, redness, limited move-

${ }^{1}$ Harran Üniversitesi Tıp Fakültesi, Fiziksel Tıp Ve Rehabilitasyon Ana Bilim Dalı, Şanlıurfa, Türkiye

${ }^{2}$ Harran Üniversitesi Tıp Fakültesi, Radyoloji Ana Bilim Dalı, Şanlıurfa, Türkiye

Correspondence: Ahmet Boyacı,

Harran Üniversitesi Tıp Fakültesi, Fiziksel Tıp ve Rehabilitasyon Ana Bilim Dalı, Şanlıurfa, Türkiye Email: drboya-ci@hotmail.com Received: 08.01.2013, Accepted: 31.03.2013

Copyright (C) JCEI / Journal of Clinical and Experimental Investigations 2013, All rights reserved 
ment and inability to walk unaided. As the result of a fall from height approximately 3 months previously, the patient underwent surgery in the Neurosurgical Clinic for L1 and L2 vertebrae fractures and bilateral calcaneus fracture. In the operation T11-L3 posterior stabilization and T12- L2 laminectomy was performed. Plaster casts were applied to both feet for 45 days for the bilateral calcaneus fractures and 2 weeks after the plasters were removed, the complaints started of pain, swelling and redness in both feet. There was nothing remarkable in the patient history. In the locomotor system examination, muscle strength was bilateral L2, L3: $5 / 5$, L4, L5, S1: 1/5, bilateral L4, L5, S1 hypoesthesic, anal sensation was preserved, DTR could not be taken. Movement of both ankles was limited and painful, both feet had edema and pink-purple color changes, were cold and sensitive. The patient was able to walk a short distance with help. There was no fecal and urinary incontinence. Residual urine volume was $20 \mathrm{cc}$. Laboratory findings were normal, including complete blood count, erythrocyte sedimentation rate, C-reactive protein, rheumatoid factor, kidney, liver and thyroid function tests, serum calcium, phosphorus, alkaline phosphatase levels. In the radiographic examination, the ankle radiographs of both feet showed diffuse soft tissue swelling of the plantar sides (Figure 1).

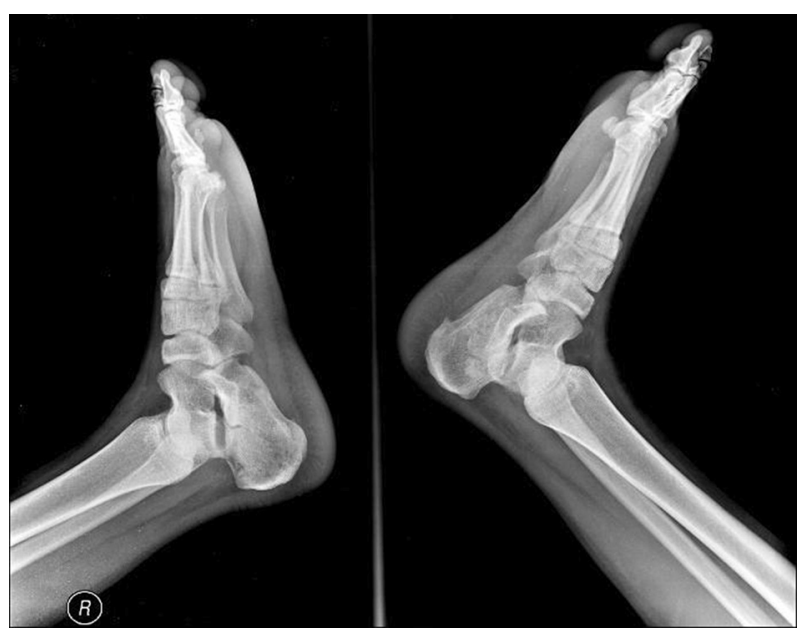

Figure 1. Lateral radiograph of both ankles show diffuse soft tissue swelling of the plantar sides

In three-phase bone scintigraphy, in the blood pool phase, increased diffuse activity involvement was observed in both feet and the ankle area and in the delayed phase, periarticular involvement was determined (Figure 2). These findings were evaluated as bilateral CRPS-1 in the lower extremities. Treatment was applied of $200 \mathrm{U} /$ day nasal calcitonin, analgesic anti-inflammatory medication, contrast bath for both feet, TENS, intermittent US $\left(1 \mathrm{w} / \mathrm{cm}^{2}\right)$ and passive range of movement exercises. Following the rehabilitation program, the patient was able to walk with short leg orthoses and crutches. The complaints in both feet had significantly reduced. The patient was discharged with the recommendation to continue the medical and exercise therapy.

\section{DISCUSSION}

The pathophysiology of CRPS is not yet fully known. However it is thought that regional inflammation, peripheral sensitization, central sensitization, neurogenic inflammation and microvascular dysfunction play a role in the pathophysiology [3]. The pathophysiological process of CRPS starts with a peripheral injury caused by subclinical nerve damage and neurogenic inflammation [3]. Through initial changes in the A delta and $C$ fibers, these changes in the dorsal root ganglion cause abnormal connections in the nervous system leading to inflammatory peptide release, sensitization and sympathetic origin pain. In the long-term, change develops in neuropeptide production and abnormalities in spinal and supraspinal inhibitors and in the excitator route [3].

CRPS is separated into Type 1 and Type 2. CRPS which develops after a nociceptive event is labeled as Type 1 and when it develops following peripheral nerve damage, Type 2 [5]. Epidemiological data related to Type 1 CRPS is limited. A study using 1994 International Association for the Study of Pain (IASP) diagnostic criteria reported incidence as $26.2 / 100,000$ per year [6]. Location often tends to be in the distal of extremities and often in a single extremity. It is more often seen in the upper extremities than the lower extremities [7] and threefold more in females than males [8].

Pain, allodynia, hyperalgesia, changes in color and temperature in the affected extremity, increased sweating, edema, weakness, movement incapacity, tremor, muscle spasm, dystonic characteristics, contracture, increased hairiness and nail changes are seen clinically in CRPS. It may be encountered in many different forms in clinical practice. For example the extremity may be hot or cold, shiny, swollen or atrophic, red or blue in color. The skin may be damp or dry. There may be localized osteoporosis in the bones on radiographs [2]. Up to 7\% of patients with typical CRPS symptoms may have no pain [4]. In the differential diagnosis, arthritis, cellulitis, osteomyelitis, deep vein thrombosis, malignancies, fractures, neuropathic pain impairment, and chronic vascular insufficiency should be considered [9]. 


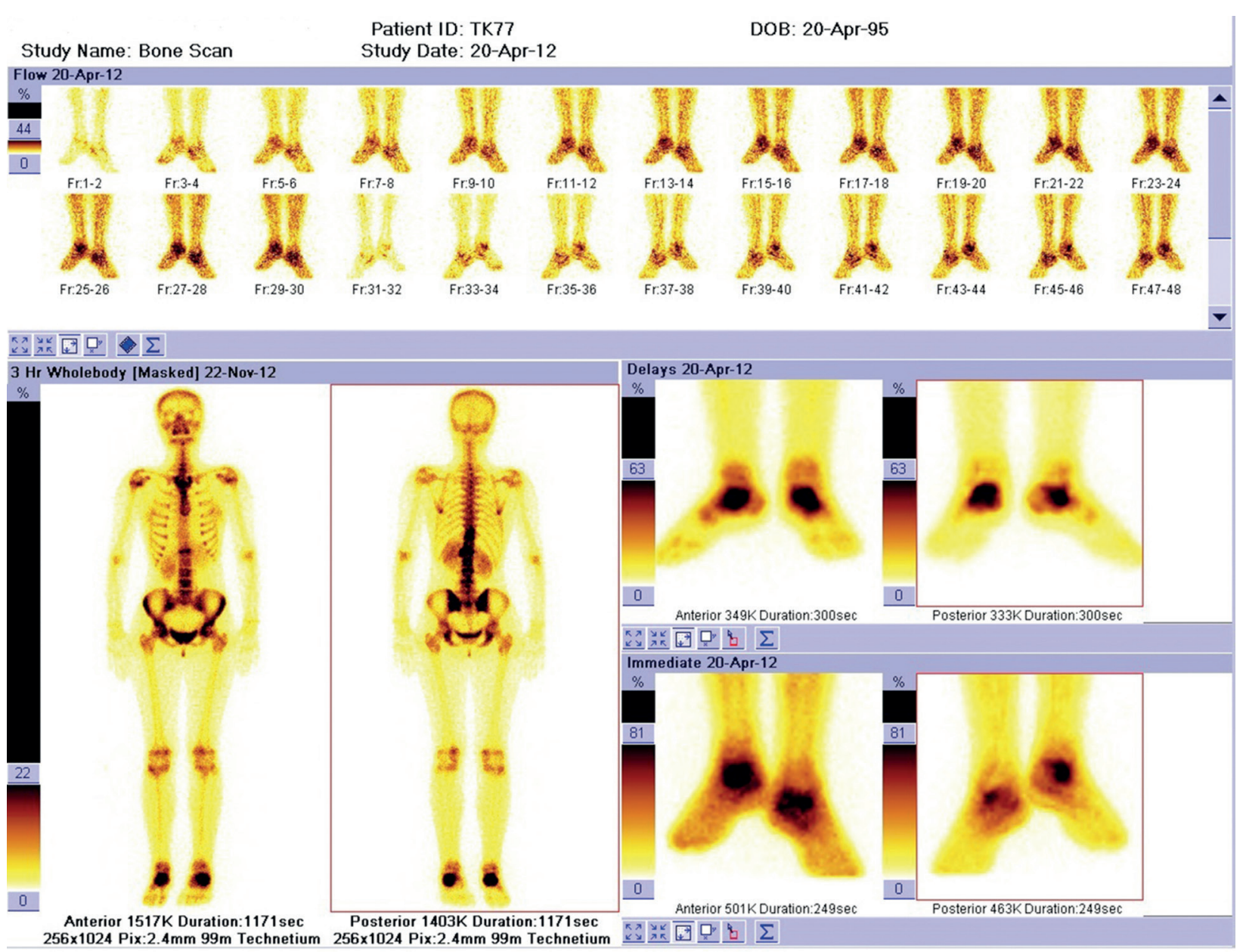

Figure 2. Periarticular increased tracer uptake is seen the delayed phase of three phase bone scan of both ankles

Although pain is a widespread complication in patients with spinal cord injuries, the development of CRPS is rare, although it has been reported in literature $[10,11]$. Two case studies have recently been published of CRPS Type-1 developing associated with bilateral calcaneus fracture $[7,12]$. The case presented here is of CRPS which developed following bilateral calcaneus fracture and spinal cord injury. There was no history of the use of any medication with a predisposition to CRPS Type 1 prior to the injury. However, as the case presented here had psychological problems that could have made the patient susceptible to CRPS Type 1. In addition a genetic predisposition or that the fractures were bilateral could have facilitated the CRPS Type 1. The central cortical mechanism could be an indicator in the explanation of the development of bilateral CRPS following spinal cord injury and bilateral calcaneus fracture. In multiple involvements, rather than mechanical factors, genetic, psychological and immunological factors may explain the development of bilateral CRPS.
To regain extremity function in CRPS cases, early diagnosis and starting a rehabilitation program is extremely important. There is no absolutely proven, effective treatment for CRPS-1 cases. Treatment must be managed in a multidisciplinary manner. The aim of treatment should be to firstly reduce edema and pain, then to progress joint movement by increasing muscle strength and finally to provide restoration of full function. The treatment options include physical therapies, mirror visual feedback, medication and surgery. Calcitonin, biphosphonates, capsaicin creams and vitamin $\mathrm{C}$ have been found to be useful in acute CRPS [13].

In conclusion, a higher possibility should be expected of CRPS Type 1 developing in spinal cord injuries and bilateral extremity injuries and an effective treatment protocol should be applied in the early stages. 


\section{REFERENCES}

1. de Rooij AM, Perez RS, Huygen FJ, et al. Spontaneous onset of complex regional pain syndrome. Eur J Pain 2010;14:510-513.

2. Goebel A. Complex regional pain syndrome in adults. Rheumatology (Oxford) 2011;50:1739-1750.

3. Gorodkin R, Herrick AL. Complex regional pain syndrome (reflex sympathetic dystrophy). In: Hochberg MC, Silman AJ, Smolen JS, Weinblatt ME, Weisman $\mathrm{MH}$, editors. Rheumatology, $5^{\text {th }}$ edition. Philadelphia, PA, Mosby, 2011:797-804.

4. Veldman PH, Reynen HM, Arntz IE, Goris RJA. Signs and symptoms of reflex sympathetic dystrophy: prospective study of 829 patients. Lancet 1993;342:10121016.

5. Önder B, Selçuk B, Kurtaran A, ve ark. Hemiplejik hastada alt ekstremitede gelişen kompleks bölgesel ağrı sendromu: Bir olgu sunumu. Türk Fiz Tıp Rehab Derg 2011;57:245-247.

6. de Mos M, de Bruijn AG, Huygen FJ, et al. The incidence of complex regional pain syndrome: a population-based study. Pain 2007;129:12-20.
7. Altındağ Ö, Aydeniz A, Gürsoy S, Bukan TH. Bilateral ayak tutulumu gösteren tedaviye dirençli kompleks bölgesel ağrı sendromu tip 1: Bir olgu sunumu. Turk J Rheumatol 2009:24;103-105.

8. Stanton-Hicks M. Complex regional pain syndrome. Anesthesiol Clin North Am 2003;21:733-744.

9. Ofluoğlu D, Akyüz G. Kompleks bölgesel ağrı sendromu Tip 1: Genel Klinik Yaklaşım. Türk Fiz Tıp Rehab Derg 2007;54:112-115

10. Wainapel SF, Freed MM. Reflex sympathetic dystrophy in quadriplegia: case report. Arch Phys Med Rehabil 1984;65:35-36.

11. Gallien P, Nicolas B, Robineau S, et al. The reflex sympathetic dystrophy syndrome in patients who have had a spinal cord injury. Paraplegia 1995;33:715-720.

12. Hız Ö, Ediz L, Ceylan MF, ve ark. Bilateral kalkaneus kırığı sonrasında bilateral kompleks bölgesel ağrıi sendromu: Olgu sunumu. Osteoporoz Dünyasından 2010;16:38-40.

13. Price DD, Long S, Wilsey B, et al. Analysis of peak magnitude and duration of analgesia produced by local anaesthetics injected into sympathetic ganglia of complex regional pain syndrome patients. Clin J Pain 1998,14:216-226. 